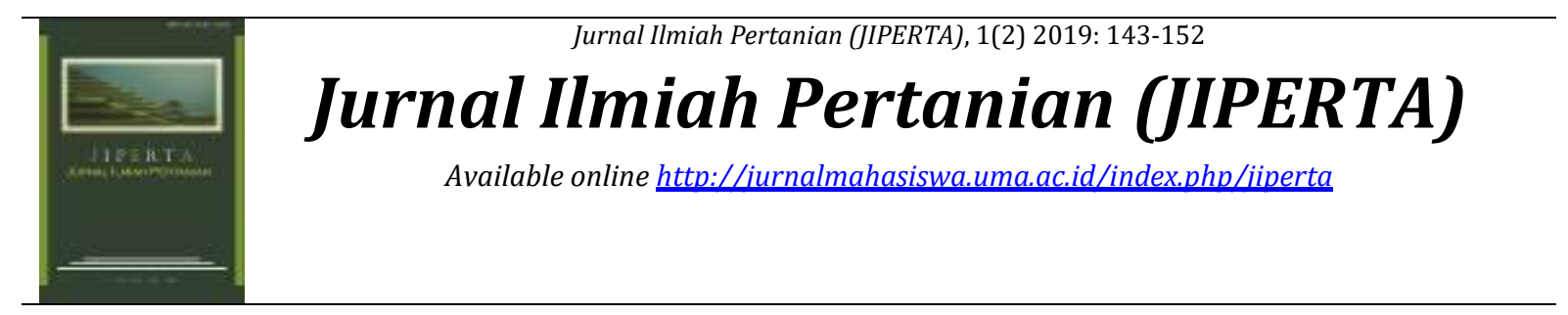

\title{
Pengaruh Pemberian Pupuk Organik Cair Kandang Kelinci dan Kompos Limbah Baglog pada Pertumbuhan Bibit Kakao (Theobroma Cacao L.) di Polibeg
}

\section{The Effect of Providing Liquid Organic Fertilizer of Rabbit Cages and Compost of Baglog on the Growth of Cocoa Seedlings (Theobroma cacao $L$.) in polybags}

\author{
Redho Anggara Nobriama1), Erwin Pane ${ }^{2), ~ S u m i h a r ~ H u t a p e a 1) * ~}$
}

1) Program Studi Agroteknologi, Fakultas Pertanian, Universitas Medan Area, Indonesia

\section{Abstrak}

Kakao merupakan komuditas perkebunan unggulan di Indonesia sehingga produksinya harus selalu ditingkatkan. Tujuan penelitian ini untuk memperoleh data pertumbuhan bibit kakao (Theobroma cacao L.) dengan pengaplikasian pupuk organik cair kandang kelinci dan kompos limbah baglog dengan dosis yang berbeda. Penelitian ini dilaksanakan dilahan percobaan Fakultas Pertanian Universitas Medan Area yang berlokasi di jalan PBSI no.1 Medan Estate. Penelitian dilaksanakan mulai bulan Juli sampai bulan November 2018. Menggunakan Rancangan Acak Kelompok (RAK) Faktorial dengan dua ulangan. Faktor pertama yang diuji adalah pupuk organik cair kandang kelinci yaitu U0 = tanpa POC, U1= konsentrasi 5\% (50 ml POC/liter), U2= konsentrasi $10 \%$ (100 ml POC/liter), U3= konsentrasi 15\% (150 ml POC/liter). Faktor kedua adalah kompos limbah baglog yaitu L0= tanpa kompos limbah baglog, L1= $20 \%$ kompos limbah baglog $(600 \mathrm{~g})+80 \%$ top soil $(2.400 \mathrm{~g})$, L2 $=40 \%$ kompos limbah baglog $(1.200 \mathrm{~g})+60 \%$ top soil $(1.800 \mathrm{~g}), \mathrm{L3}=60 \%$ kompos limbah baglog $(1.800 \mathrm{~g})+40 \%$ top soil (1.200g). Hasil penelitian menunjukan bahwa pemberian kompos limbah baglog dapat meningkatkan pertumbuhan (tinggi tanaman, jumlah daun, diameter batang dan bobot basah tajuk) bibit kakao.

Kata Kunci: Bibit kakao, Kompos limbah baglog, POC kandang kelinci

\begin{abstract}
Cacao is one of the predominant plantation in Indonesia so that the production should be improved constantly. The purpose of this researce was to obtain data on the growth of cacao seedlings (Theobroma cacao L.) by applying rabbit cage liquid organic fertilizer and composting baglog waste with different doses. This research was carried out at the Medan Area faculty of agriculture experiment area located on the street PBSI No.1 Medan Estate. The research was conducted from July to November 2018. Using Factorial Randomized Group Desing (RGD) with two replications. The first factor tested was rabbit cage liquid organic fertilizer namely UO= without POC, U1= consentration $5 \%$ (50 ml POC/liter), U2= consentration $10 \%$ (100 ml POC/liter), U3= consentration 15\% (150 ml POC/liter). The second factor is baglog waste compost which is $L 0=$ without compost baglog waste, $L 1=20 \%$ baglog compost waste $(600 \mathrm{~g})+80 \%$ top soil $(2.400 \mathrm{~g}), \mathrm{L2}=40 \%$ baglog compost waste $(1.200 \mathrm{~g})+60 \%$ top soil $(1.800 \mathrm{~g}), \mathrm{L3}=60 \%$ baglog compost waste $(1.800 \mathrm{~g})+40 \%$ top soil $(1.200 \mathrm{~g})$. The results showed that administration of baglog waste compost can increase growth ( plant height, number of leaves, stem diameter and canopy wet weight) of cocoa seedlings
\end{abstract}

Keywords: Cacao seedlings, Compost baglog waste, POC rabbit cage

How to Cite: Redho, A.N, Erwin P \& Sumihar, H. (2020) pengaruh pemberian pupuk organik cair kandang kelinci dan kompos limbah baglog pada pertumbuhan bibit Kakao (theobroma cacao l.) Di polibeg. Jurnal Ilmiah Pertanian (JIPERTA), 6 (2): 106-111

*E-mail: redho1996@gmail.com

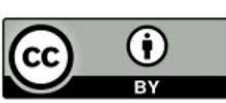


Redho Anggara Nobriama, Erwin Pane \& Sumihar Hutapea, pengaruh pemberian pupuk organik cair kandang kelinci dan kompos limbah baglog pada pertumbuhan bibit Kakao (theobroma cacao l.)

\section{PENDAHULUAN}

Kakao (Theobroma cacao L.) merupakan salah satu komoditas perkebunan yang sesuai untuk perkebunan rakyat, karena tanaman ini dapat berbunga dan berbuah sepanjang tahun, sehingga dapat menjadi sumber pendapatan harian atau mingguan bagi pekebun (Rahardjo, 2017; Ulfa, 2019). Kakao adalah komoditas unggulan perkebunan yang prospektif serta berpeluang besar dalam meningkatkan kesejahteraan masyarakat karena sebagian besar diusahakan melalui perkebunan rakyat (syahza, 2011).

Kakao sebagai komoditas unggulan perkebunan nasional menghasilkan devisa terbanyak setelah kelapa sawit dan karet (Pusat Data dan Sistem Informasi Pertanian, 2016). Produksi Indonesia mencapai 15\% dari produksi biji kakao dunia dan menempati peringkat ketiga dunia setelah Pantai Gading dan Ghana. Pada tahun 2011, produksi kakao Indonesia menurun drastis dari 837.918 ton menjadi 712.231 ton (tahun 2010). Pada tahun 2012, produksi kakao nasional mulai mengalami peningkatan menjadi 740.513 ton dan berfluktuasi pada rentang 720.862 ton (tahun 2013) dan 728.414 ton (tahun 2014) (Direktorat Jenderal Perkebunan, 2015). Lalu pada tahun 2016 kembali mengalami penurunan sebesar 656.817 ton, kemudian pada tahun 2017688.345 ton (Direktorat Jendral Perkebunan 2017). Penurunan produksi ini diakibatkan oleh banyak faktor, antara lain faktor lingkungan, teknik budidaya, dan pascapanen.

Salah satu usaha yang dapat dikelola untuk meningkatkan kualitas maupun kuantitas produksi kakao adalah dengan memperhatikan aspek dari budidaya tanaman kakao itu sendiri. Diantaranya adalah pengelolaan tanah, pemupukan, pemangkasan, pengendalian hama dan penyakit, serta pemberian zat pengatur tumbuh. Hal yang juga tidak kalah pentingnya dalam budidaya tanaman kakao adalah penyediaan bahan tanam dalam pembibitan, karena dari pembibitan inilah akan didapatkan bahan tanam yang layak untuk ditanam di lapangan yang nantinya akan menghasilkan bibit tanaman kakao yang mampu berproduksi secara maksimal (Purba, 2014).

Keberhasilan pengembangan kakao ditentukan oleh tersedianya bibit dalam jumlah yang cukup dan memperhatikan budidayanya. Salah satu tindakan budidaya kakao yaitu pada penyediaan bibit yang berkualitas. Kualitas bibit sangat menentukan pertumbuhan dan produktifitas kakao. Untuk mendapatkan bibit yang berkualitas adalah melalui proses pembibitan (Panggabean, 2015).

Salah satu kendala untuk meningkatkan kualitas kakao di pembibitan antara lain : (a) faktor fisik, seperti tanah dan iklim terutama curah hujan, sebaran hujan dan suhu udara; (b) faktor biologis, terutama hama, penyakit dan gulma; (c) faktor sosial yang meliputi rendahnya adopsi teknologi oleh petani yang berakibat beragamnya pengelolaan tanaman di lapangan. Pembibitan membutuhkan tindakan seperti pemberian pupuk yang bertujuan untuk memperbaiki kesuburan tanah dan menambah unsur hara tertentu di dalam tanah. Pupuk yang diberikan dapat dalam bentuk pupuk organik. Manfaat bahan organik secara fisik memperbaiki struktur dan meningkatkan kapasitas tanah menyimpan air, secara kimiawi meningkatkan daya sangga tanah terhadap perubahan $\mathrm{pH}$ dan secara biologi merupakan sumber energi bagi 
mikroorganisme tanah yang berperan penting dalam proses dekomposisi dan pelepasan unsur hara dalam ekosistem tanah. Ada beberapa jenis pupuk organik yang berasal dari alam yaitu pupuk kandang, pupuk hijau, kompos, humus, pupuk hayati dan limbah industri pertanian (Yunita dkk, 2017; Parlaungan, 2018).

Pemberian pupuk organik untuk bibit kakao dapat berupa padat ataupun cair. Salah satu bahan yang dapat digunakan sebagai bahan baku pembuatan pupuk organik adalah limbah kandang kelinci. Berdasarkan hasil kajian badan penelitian ternak (Balitnak) pada tahun 2005 menyatakan bahwa kotoran dan urin kelinci dapat dimanfaatkan sebagai pestisida dan pupuk organik. Hal tersebut dikarenakan kadar Nitrogen kususnya pada urin kelinci lebih tinggi daripada hewan herbifora lainnya seperti sapi dan kambing. Hal tersebut dikarenakan kelinci hanya makan daun saja. Kandungan kotoran/urin kelinci yaitu ; N : 2,72\%, P : 1,1\%, dan K : 0,5\% (Kusnendar, 2013).

Selain pemberian pupuk organik cair kandang kelinci, upaya lain yang dapat dilakukan adalah dengan menggunakan bahan organik yang dapat berasal dari limbah industri pertanian yaitu limbah media tanam jamur (baglog). Limbah media tanam jamur (baglog) yang sudah tidak produktif dan tidak dimanfaatkan akan menjadi sampah yang menumpuk dan mengotori lingkungan. Saat ini banyak petani jamur yang sudah mulai memanfaatkan limbah baglog tersebut menjadi sesuatu yang mempunyai nilai tambah bahkan dapat dijadikan sebagai usaha tambahan. Pemanfaatan limbah baglog tersebut antara lain untuk media ternak belut, media ternak cacing, bahan baku pupuk organik dan pakan bagi ternak (Pupuk dan Wartakusuma, 2014).

Limbah baglog dapat dimanfaatkan sebagai pupuk organik yang berguna memperbaiki struktur dan kesuburan tanah, meningkatkan daya simpan dan daya serap air, memperbaiki kondisi biologi dan kimia tanah, memperkaya unsur hara makro dan mikro serta tidak mencemari lingkungan dan aman bagi manusia. Pupuk dan Kusuma (2014) telah menganalisis kandungan $\mathrm{N}, \mathrm{P}$, dan $\mathrm{K}$ dalam limbah baglog tersebut sehingga dihasilkan kandungan seperti $\mathrm{N}$ : 0,87\%, P : 0,05\% dan $\mathrm{K}: 5,7 \%$. Berdasarkan uraian diatas bahwa limbah kandang kelinci dan limbah media tanam jamur (baglog) dapat dimanfaatkan sebagai bahan organik yang dapat memperbaiki kondisi tanah dan sebagai nutrisi untuk pertumbuhan tanaman. Oleh karena itu penulis tertarik untuk melakukan penelitian mengenai pengaruh pemberian pupuk organik cair kandang kelinci dan pupuk kompos limbah baglog pada pertumbuhan bibit kakao (Theobroma cacao L.) di polibeg.

\section{METODE PENELITIAN \\ Rancangan Penelitian}

Penelitian ini dilakukan dengan menggunakan Rancangan Acak Kelompok (RAK) Faktorial yang terdiri dari 2 faktor perlakuan yaitu, pemberian pupuk organik cair kandang kelinci yang terdiri dari 4 taraf perlakuan,U0 = Kontrol (tidak memberi pupuk organik cair kandang kelinci), U1= Pupuk organik cair kandang kelinci $50 \mathrm{ml} / \mathrm{liter}$ air (5\%), U2= Pupuk organik cair kandang kelinci $100 \mathrm{ml} / \mathrm{liter}$ air (10\%), U3= Pupuk organik cair kandang kelinci $150 \mathrm{ml} /$ liter air (15\%). Pemberian kompos limbah baglog yang terdiri dari 4 taraf perlakuan, L0 = Kontrol (tidak memberi kompos limbah baglog), $\mathrm{L} 1=20 \%$ kompos limbah baglog $(600 \mathrm{~g})+80 \%$ top soil $(2.400 \mathrm{~g}), \mathrm{L} 2=40 \%$ kompos 
Redho Anggara Nobriama, Erwin Pane \& Sumihar Hutapea, pengaruh pemberian pupuk organik cair kandang kelinci dan kompos limbah baglog pada pertumbuhan bibit Kakao (theobroma cacao l.)

limbah baglog $(1.200 \mathrm{~g})+60 \%$ top soil $(1.800 \mathrm{~g}), \mathrm{L3}=60 \%$ kompos limbah baglog $(1.800 \mathrm{~g})+40 \%$ top soil $(1.200 \mathrm{~g})$.

Berdasarkan taraf perlakuan yang digunakan maka didapatkan 16 kombinasi perlakuan dan ulangan sebanyak 2 ulangan, jumlah plot penelitian 32 plot, ukuran plot penelitian $70 \times 70 \mathrm{~cm}$, jumlah tanaman per plot 5 tanaman, jumlah tanaman sampel per plot 3 tanaman, jumlah tanaman keseluruhan 160 tanaman, jumlah tanaman sampel keseluruhan 96 tanaman, jarak antar plot $30 \mathrm{~cm}$, jarak antar ulangan $50 \mathrm{~cm}$. Denah plot penelitian dapat dilihat di Lampiran 3 dan 4 pada halaman 54 dan 55.Berdasarkan taraf perlakuan yang digunakan maka didapatkan 16 kombinasi perlakuan dan ulangan sebanyak 2 ulangan, jumlah plot penelitian 32 plot, ukuran plot penelitian $70 \times 70 \mathrm{~cm}$, jumlah tanaman per plot 5 tanaman, jumlah tanaman sampel per plot 3 tanaman, jumlah tanaman keseluruhan 160 tanaman, jumlah tanaman sampel keseluruhan 96 tanaman, jarak antar plot $30 \mathrm{~cm}$, jarak antar ulangan $50 \mathrm{~cm}$. Denah plot penelitian dapat dilihat di Lampiran 3 dan 4 pada halaman 54 dan 55.

\section{Pembuatan Limbah Baglog dan POC Kandang Kelinci}

Langkah awal yang dilakukan adalah mengumpulkan limbah baglog sebanyak 150 kg yang masih dalam keadaan utuh terbungkus oleh plastik, yang di ambil dari Sumatera kumbung Jamur, Jalan Benteng Hilir Ujung no 19, Kelurahan Bandar khalipah Kecamatan Percut Sei Tuan. Dengan komposisi dalam 1 goni yaitu $35 \mathrm{~kg}$ serbuk gergaji, $2 \mathrm{~kg}$ dedak, 1 $\mathrm{kg}$ tepung jagung, $240 \mathrm{~g}$ dolomit dan $65 \%$ air, berdasarkan hasil wawancara pemilik kumbung yaitu Bapak Delvi Setiawan. Untuk pembuatan tahap awal yaitu mememecahkan baglog agar menjadi remah dan tidak menggumpal, kemudian air yang digunakan sebanyak 25 liter, EM4 1 liter untuk mendekomposisi bahan organic.

mengumpulkan urine yg berasal dari kandang kelinci yang bercampur dengan kotoran kelinci. Kotoran cair kandang kelinci tersebut berasal dari jenis kelinci American Fuzzy lop, Anggora Lokal, English Anggora dan Himalayan dengan umur 1 bulan sampai 1 tahun, lalu disaring dan dimasukan kedalam tong sebanyak 20 liter yang di ambil dari pemilik yaitu Aditya Andriansyah, Jalan Polonia Komplek TNI AU Gang Elang 1 Blok C 14. Setelah itu campurkan larutan EM4 sebanyak $200 \mathrm{ml}$ dan $200 \mathrm{~g}$ gula merah yang telah dicairkan dalam 1,5 liter air.

\section{Persiapan Lahan, Penanaman, dan Pemeliharaan}

Lahan penelitian yang akan digunakan terlebih dahulu diukur menggunakan meteran, dan luasan lahan yang dibutuhkan yaitu panjang $9 \mathrm{~m}$ dan lebar $5 \mathrm{~m}$, lalu dibersihkan dari gulma dengan cara di babat, Setelah areal bersih, dilakukanlah pengolahan tanah dengan menarik dan meratakan tanah menggunakan traktor. Setelah itu pancang bentuk plot-plot yang berukuran 70 x $70 \mathrm{~cm}$ menggunakan tali plastik, kemudian naikan tanah dan bentuklah plot-plot menggunakan cangkul dengan ketinggian $15 \mathrm{~cm}$ sebanyak 32 plot. Jarak antar plot yaitu $30 \mathrm{~cm}$ dan jarak antar ulangan $50 \mathrm{~cm}$. Naungan diperlukan untuk menghindari pancaran sinar matahari langsung terutama pada saat awal pembibitan. Naungan memakai paranet 60 dan $70 \%$ dengan tinggi naungan 2 
meter. Sedangkan Benih yang digunakan adalah benih kakao varietas Lindak yaitu klon RCC 70 yang diambil dari pohon induk yang telah berumur lebih dari 15 tahun dari Pusat Penelitian Kelapa Sawit (PPKS) Rispa Medan.

Benih kakao yang sudah berkecambah di tanam ditengah polibeg dengan cara manual secara tugal dengan kedalaman tanam $2 \mathrm{~cm}$. Penanaman bibit. Aplikasi pupuk organik cair kandang kelinci dilakukan pada saat umur tanaman dua minggu setelah tanam. Pupuk organik cair kandang kelinci dilarutkan terlebih dahulu dengan 1 liter air. Pemeliharaan, pengamatan sejumlah parameter pertumbuhan vegetative dan produksi serta analisis data dilakukan dalam satu waktu. Data yang telah dikumpulkan selanjutnya dianalisis sesuai kaidah statistikan RAK Faktorial dua factor.

\section{HASIL DAN PEMBAHASAN}

\section{Pengamatan Tinggi Tanaman}

Data pengamatan tinggi tanaman kakao dan hasil sidik ragam tinggi tanaman kakao pada pemberian pupuk organik cair kandang kelinci dan pupuk kompos limbah baglog pada umur 1 sampai 9 Minggu Setelah Tanam (MST) telah dianalisis. Rangkuman hasil sidik ragam tinggi tanaman kakao dari umur 1 sampai 9 MST disajikan pada Tabel 1.

Table 1. Rangkuman Hasil Sidik Ragam Tinggi Tanaman Kakao pada Pemberian Pupuk Organik Cair Kandang Kelinci dan Kompos Limbah Baglog.

\begin{tabular}{|c|c|c|c|c|c|c|c|c|c|c|c|}
\hline \multirow{3}{*}{ SK } & \multicolumn{9}{|c|}{ Tinggi Tanaman $(\mathrm{cm})$} & \multirow{2}{*}{\multicolumn{2}{|c|}{ F. Tabel }} \\
\hline & \multicolumn{9}{|c|}{ F. Hitung Umur (MST) } & & \\
\hline & 1 & 2 & 3 & 4 & 5 & 6 & 7 & 8 & 9 & F. 05 & F.01 \\
\hline Kelompok & $0,54 \mathrm{tn}$ & $0,55 \mathrm{tn}$ & 0,09 tn & 0,00 tn & $0,16 \mathrm{tn}$ & $0,42 \mathrm{tn}$ & $0,11 \mathrm{tn}$ & $0,31 \mathrm{tn}$ & $0,66 \mathrm{tn}$ & 4,54 & 6,68 \\
\hline $\mathrm{U}$ & $0,98 \mathrm{tn}$ & $0,85 \mathrm{tn}$ & $1,37 \mathrm{tn}$ & 0,90 tn & $0,68 \mathrm{tn}$ & 0,90 tn & $0,26 \mathrm{tn}$ & $0,20 \mathrm{tn}$ & $0,16 \mathrm{tn}$ & 3,29 & 5,42 \\
\hline $\mathrm{L}$ & $1,46 \mathrm{tn}$ & $1,95 \mathrm{tn}$ & $2,95 \mathrm{tn}$ & $1,36 \mathrm{tn}$ & $1,40 \mathrm{tn}$ & $3,56 *$ & $4,28 *$ & $3,38^{*}$ & $3,63 *$ & 3,29 & 5,42 \\
\hline UX L & $0,85 \mathrm{tn}$ & $1,26 \mathrm{tn}$ & $1,00 \mathrm{tn}$ & $0,87 \mathrm{tn}$ & $0,62 \mathrm{tn}$ & $0,96 \mathrm{tn}$ & $0,54 \mathrm{tn}$ & $0,54 \mathrm{tn}$ & $0,54 \mathrm{tn}$ & 3,59 & 3,89 \\
\hline $\mathrm{KK}$ & 9,28 & 8,32 & 8,08 & 9,76 & 10,13 & 7,66 & 9,10 & 8,86 & 8,69 & $\%$ & \\
\hline
\end{tabular}

Tabel 1 menunjukkan bahwa pemberian perlakuan pupuk organik cair kandang kelinci (U) tidak berpegaruh nyata terhadap pertumbuhan bibit tanaman kakao pada umur 1 sampai 9 MST, dan perlakuan kompos limbah baglog (L) berpengaruh tidak nyata pada pengamatan 1 MST sampai 5 MST, sedangkan pada umur 6 MST sampai 9 MST, berpengaruh nyata dalam meningkatkan pertumbuhan tinggi tanaman kakao. Lalu perlakuan kombinasi pupuk organik cair kandang kelinci dan kompos limbah baglog (UxL) tidak memberikan pengaruh yang nyata pada umur 1 MST sampai 9 MST.

data pengamatan Agroklimatologi menunjukan bahwa curah hujan pada bulan September $272 \mathrm{~mm}$, Oktober $417 \mathrm{~mm}$, dan November $320 \mathrm{~mm}$. Sifat dari pupuk cair yang mudah hilang, bisa saja karena tercuci oleh air hujan sehingga tidak berpengaruh terhadap tinggi tanaman (Saleh and Jayanti, 2017) menyatakan bahwa curah hujan sangat berpengaruh cukup signifikan terhadap pertumbuhan tanaman. Jumlah curah hujan secara keseluruhan sangat penting dalam menentukan pertumbuhan tanaman, apakah berpengaruh baik atau berpengaruh buruk. 
Redho Anggara Nobriama, Erwin Pane \& Sumihar Hutapea, pengaruh pemberian pupuk organik cair kandang kelinci dan kompos limbah baglog pada pertumbuhan bibit Kakao (theobroma cacao l.)

Hasil uji beda rata-rata tinggi tanaman bibit kakao pada pengamatan 9 MST akibat pemberian kompos limbah baglog menunjukkan bahwa, perlakuan terbaik parameter tinggi tanaman kakao terlihat pada perlakuan L3. Disajikan pada Tabel 2.

Table 2. Rataan Tinggi Bibit Tanaman Kakao Akibat Pemberian Kompos Limbah Baglog Pada Pengamatan 9 MST.

\begin{tabular}{ccc}
\hline Perlakuan & Tinggi Bibit $(\mathrm{cm})$ & $\alpha .05$ \\
\hline L0 & 22,50 & $\mathrm{~b}$ \\
L1 & 21,67 & $\mathrm{c}$ \\
L2 & 22,67 & $\mathrm{~b}$ \\
L3 & 24,81 & $\mathrm{a}$ \\
\hline
\end{tabular}

Keterangan : Angka-angka yang diikuti notasi huruf yang berbeda pada satu kolom menunjukkan berbeda nyata pada taraf uji 0,05 (huruf kecil) dan berbeda sangat nyata pada taraf uji 0,01 (huruf besar).

pemberian kompos limbah baglog menunjukkan, perlakuan L3 berbeda nyata terhadap perlakuan L2 dan L0 dan pada perlakuan L2 dan L0 menunjukkan bahwa berbeda nyata terhadap perlakuan L1 sedangkan L0 berbeda nyata terhadap L1. Hal ini diduga bahwa pemberian perlakuan L1 belum memberikan pengaruh yang baik pada tinggi tanaman kakao sedangkan pada perlakuan L0 telah tercukupi unsur hara yang terdapat di dalam tanah tanpa pemberian perlakuan. Hal tersebut sesuai dengan hukum the law of diminishing returns dimana apabila suatu tanaman sudah tercukupi akan kebutuhan unsur hara dan jika ditambah maka pertumbuhan yang akan didapatkan bukan semakin naik tapi turun. Sesuai dengan pandapat Indrawan et al. (2015) yang menyatakan bahwa dengan penambahan unsur $\mathrm{N}$ ke dalam tanah dapat merangsang jaringan meristematik yang semakin aktif membelah sehingga memacu pertumbuhan bibit kakao khususnya tinggi tanaman, karena peran utama unsur $\mathrm{N}$ bagi tanaman adalah merangsang pertumbuhan tanaman khususnya batang, cabang dan daun. Oviyanti et al. (2016) juga menambahkan bahwa kandungan unsur hara terutama Nitrogen mampu mendorong dan mempercepat pertumbuhan dan pertambahan tinggi tanamanNaibaho and Nelvia juga menambahkan bahwa unsur $\mathrm{N}$ sangat dibutuhkan tanaman untuk sintesa asam-asam amino dan protein, terutama pada titik-titik tumbuh tanaman sehingga mempercepat proses pertumbuhan tanaman seperti pembelahan sel dan perpanjangan sel sehingga meningkatkan tinggi tanaman. Hal in sejalan dengan pendapat (Kuvaini and Surbakti, 2019) yang menyatakan bahwa pada saat Nitrogen tercukupi, maka kerja auksin akan terpacu sehingga akan mempengaruhi pertumbuhan tinggi tanaman.

\section{Diameter Batang (Cm)}

Rangkuman hasil sidik ragam diameter batang tanaman kakao dari umur 1 sampai 9 MST disajikan pada Tabel 3. 
Table 3. Rangkuman Hasil Sidik Ragam Diameter Batang Tanaman Kakao pada Pemberian Pupuk Organik Cair Kandang Kelinci dan Kompos Limbah Baglog.

\begin{tabular}{ccccccccccccc}
\hline & \multicolumn{1}{c}{ SK } & \multicolumn{10}{c}{ F. Hitung Umur (MST) } & \multirow{2}{*}{ F. Tabel } \\
\cline { 2 - 11 } & 1 & 2 & 3 & 4 & 5 & 6 & 7 & 8 & 9 & F. 05 & F.01 \\
\hline Kelompok & 2,14 tn & 1,55 tn & 0,24 tn & 0,25 tn & 0,21 tn & 1,06 tn & 0,02 tn & 1,25 tn & $4,88^{*}$ & 4,54 & 6,68 \\
U & 0,98 tn & 2,07 tn & 2,14 tn & 0,51 tn & 2,29 tn & 1,19 tn & 2,24 tn & 0,47 tn & 2,65 tn & 3,29 & 5,42 \\
L & 0,63 tn & 0,11 tn & 0,08 tn & 0,59 tn & 0,21 tn & 1,16 tn & 1,43 tn & $3,44^{*}$ & $4,34^{*}$ & 3,29 & 5,42 \\
U X L & 1,31 tn & 0,80 tn & 0,71 tn & 0,28 tn & 0,56 tn & 1,50 tn & 0,85 tn & 0,50 tn & 1,18 tn & 3,59 & 3,89 \\
\hline KK & 8,68 & 7,10 & 5,88 & 11,13 & 10,85 & 10,05 & 8,19 & 7,03 & 5,36 & $\%$ \\
\hline \multicolumn{8}{c}{ Keterangan: tn = tidak nyata * = nyata }
\end{tabular}

bahan baku kotoran cair yang diambil sudah terlalu lama sehingga unsur hara yang terkandungpun berkurang sehingga tidak berpengaruh terhadap diameter batang. Sesuai dengan penelitian yang dilakukan oleh (Twantiarriani, 2015; Syahputra dkk, 2017) bahwa kandungan bahan organik yang didekomposisi akan mengalami penurunan jika dibandingkan dengan bahan bakunya. Berdasarkan pengaruh Sidik Ragam sebagaimana disajikan pada Tabel 3 dapat dijelaskan bahwa perlakuan kompos limbah baglog (L) berpengaruh tidak nyata pada pengamatan 1 MST sampai 7 MST. Widiyaningrum (2016) menyatakan rasio C/N dalam kompos menggambarkan tingkat kematangan dari kompos tersebut. Semakin tinggi nilai $\mathrm{C} / \mathrm{N}$ rasio didalam kompos menunjukkan kompos belum terurai secara sempurna atau belum matang, karena tingginya jumlah amonia dan nitrogen yang terperangkap di dalam pori- pori tumpukan kompos. Tingginya jumlah amonia dan nitrogen yang terlepas ke udara menyebabkan aktivitas mikroorganisme untuk menurunkan kadar karbon belum bekerja maksimal (Suwatanti and Widiyaningrum, 2017).

Bentuk kurva pengaruh hubungan antara pemberian kompos limbah baglog dengan dimeter batang bibit kakao dapat dilihat pada gambar 3 .

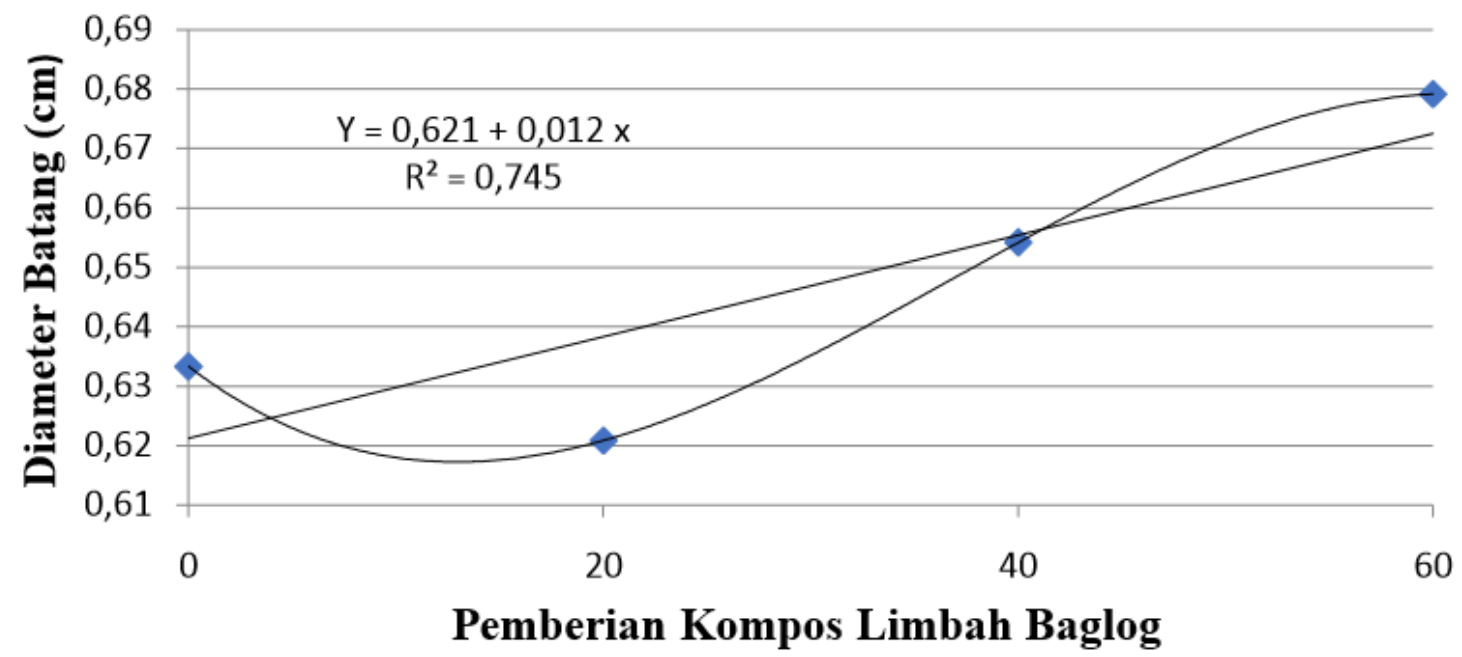

Figure 1. Kurva Pengaruh Pemberian Kompos Limbah Baglog Terhadap Diameter Batang Bibit Tanaman Kakao 
Redho Anggara Nobriama, Erwin Pane \& Sumihar Hutapea, pengaruh pemberian pupuk organik cair kandang kelinci dan kompos limbah baglog pada pertumbuhan bibit Kakao (theobroma cacao l.)

Dari Gambar 1 dapat dilihat bahwa bentuk kurva pengaruh pemberian pupuk kompos baglog dengan diameter batang bibit kakao mengikuti persamaan : $\mathrm{Y}=0,621+$ 0,012 x, yang bermakna jika pemberian pupuk kompos limbah baglog meningkat tiap persennya, maka pertambahan diameter batang tanaman akan meningkat 0,012 pertanaman bibit kakao. Nilai koefisien determinasi yang ditunjukkan yaitu $(R 2=0,745)$ yang menjelaskan bahwa 74,5\% pertambahan diameter batang bibit tanaman kakao di karenakan pengaruh pemberian pupuk kompos limbah baglog.

\section{Berat Basah Akar Tanaman}

Rangkuman hasil sidik ragam berat basah akar disajikan pada Tabel 4.

Table 4. Rangkuman Hasil Sidik Ragam Berat Basah Akar Tanaman Kakao pada Pemberian Pupuk Organik Cair kandang Kelinci dan Kompos Limbah Baglog.

\begin{tabular}{cccc}
\hline \multirow{2}{*}{ SK } & Berat Basah Akar & \multicolumn{2}{c}{ F.Tabel } \\
\cline { 3 - 4 } & Tanaman $(\mathrm{g})$ & F.05 & F.01 \\
\hline Kelompok & 0,85 tn & 4,54 & 8,68 \\
U & 1,00 tn & 3,29 & 5,42 \\
L & 1,60 tn & 3,29 & 5,42 \\
U x L & 0,48 tn & 2,59 & 3,89 \\
\hline
\end{tabular}

$\mathrm{KK}=23,08 \%$

Keterangan: tn = tidak nyata

Tabel 4 juga menunjukkan bahwa Pada perlakuan kombinasi antara pupuk organik cair kandang kelinci dan kompos limbah baglog tidak menunjukkan pengaruh yang nyata dalam meningkatkan berat basah akar tanaman kakao. Berdasarkan Tabel 4 menunjukkan bahwa tidak adanya perlakuan dari pupuk organik cair kandang kelinci dan limbah baglog serta kombinasi antara pupuk organik cair kandang kelinci dan kompos limbah baglog tidak memberikan pengaruh nyata. Diduga terjadi karena rendahnya unsur hara yg terkandung didalam tanah dan proses peningkatan akar tanaman yang belum optimal. Hal ini terjadi karena apabila tanaman belum memperoleh hara yang cukup untuk memperbanyak akar yang dibutuhkan tanaman untuk memacu bertambahnya akar bibit tanaman kakao sehingga pertumbuhan akar tanaman belum maksimal.

Indrawan et al. (2015) menyatakan perkembangan akar sangat dipengaruhi oleh struktur tanah, air dan drainase di dalam tanah yang keadaannya sangat tergantung pada bahan organik tanah. jika perakaran tanaman berkembang dengan baik maka pertumbuhan bagian tanaman lainnya akan baik juga karena akar mampu menyerap air dan unsur hara yang dibutuhkan oleh tanaman. Selanjutnya dinyatakan juga bahwa $\mathrm{pH}$ bahan organik dapat mengakibatkan keracunan tanaman seperti kation-kation $\mathrm{Al} 3+$ dan $\mathrm{Fe} 3+$ pada tanah-tanah masam dan bereaksi dengan ion-ion racun seperti $\mathrm{Cd} 2+$ dan 
Hg2+ serta kation-kation unsur mikro lain yang berada pada konsentrasi tinggi dan mengurangi ketersediaannya, ini juga disebabkan karena pori mikro pada agregatagregat tanah menjadi lebih kecil sehingga mengurangi kemampuan tanah untuk mengikat air dan tidak mendukung pertumbuhan akar tanaman.

pemberian kompos limbah baglog (L) berpengaruh nyata terhadap berat basah tajuk tanaman kakao. Hal ini membuktikan bahwa limbah baglog mengandung unsur hara yang cukup untuk pertumbuhan dan perkembangan tanaman kakao, khususnya unsur $\mathrm{N}$, sesuai dengan hasil analisis yang menunjukan bahwa kandungan $\mathrm{N}=0.92$ (tinggi). Unsur hara $\mathrm{N}$ berperan dalam merangsang pertumbuhan tanaman secara keseluruhan, maka berat basah tajuk juga semakin meningkat. Hal ini sesuai dengan Lakitan (2000)menyatakan bahwa meningkatnya jumlah unsur hara yang diserap oleh tanaman secara tidak langsung akan meningkatkan hasil fotosintat. Peningkatan hasil fotosintat menyebabkan bertambahnya bahan yang akan disimpan pada jaringan batang, daun, hasil ini yang kemudian dapat meningkatkan berat basah tajuk tanaman.

\section{SIMPULAN}

Pemberian pupuk organik cair kandang kelinci tidak memberikan pengaruh nyata terhadap tinggi tanaman, jumlah daun, diameter batang, luas daun, berat basah akar dan berat basah tajuk, pada bibit tanaman kakao di polibeg. Pemberian kompos limbah baglog memberikan pengaruh nyata terhadap tinggi tanaman, jumlah daun, diameter batang, dan berat basah tajuk, perlakuan terbaik yaitu dengan pemberian kompos limbah baglog sebanyak 60\%, namun pemberian kompos limbah baglog tidak berpengaruh nyata terhadap luas daun dan berat basah akar bibit tanaman kakao di polibeg. Pemberian perlakuan kombinasi antara pupuk organik cair kandang kelinci dan kompos limbah baglog tidak memberikan pengaruh yang nyata terhadap semua parameter.

\section{DAFTAR PUSTAKA}

DEWI RK. (2006). Produktivitas tiga bangsa kelinci di peternakan rakyat Desa Pakunden Kecamatan Ngluwar Kabupaten Magelang Jawa Tengah. Skripsi. Fakultas Peternakan Institut Pertanian Bogor, Bogor.

Panggabean P, \& Wardati W. (2015). Pengaruh Pupuk Organik Cair Dan Pupuk Kompos Kulit Buah Kakao Terhadap Pertumbuhan Bibit Kelapa Sawit (Elaeis Gueneensis Jacq.) Di Pembibitan Utama. Riau University,

PUPUK PS, \& KUSUMA W. (2014). Kandungan Nitrogen (N), Fosfor (P) Dan Kalium (K) Limbah Baglog Jamur Tiram (Pleurotus ostreatus) dan Jamur Kuping (Auricularia auricula) GUNA.

Purba ID, Irsal I, \& Ginting J. (2014). Tanggap Pertumbuhan Vegetatif Bibit Kakao (Theobroma Cacao L.) Dengan Pemberian Vermikompos Dan Air Pada Berbagai Kapasitas Lapang. Jurnal Agroekoteknologi, 2(2).

Rahardjo P. (2017). Berkebun Kopi: Penebar Swadaya.

Sipayung SB. (2010). Dampak variabilitas iklim terhadap produksi pangan di Sumatera. Jurnal Sains Dirgantara, 2(2).

Syahza A. (2011). Percepatan ekonomi pedesaan melalui pembangunan perkebunan kelapa sawit.

Indrawan I, Kusumastuti A, \& Utoyo B. (2015). Pengaruh pemberian kompos kiambang dan pupuk majemuk pada pertumbuhan bibit kakao (Theobroma cacao L.). Jurnal Agro Industri Perkebunan, 3(1), 47-58.

Kuvaini A, \& Surbakti RB. (2019). Uji Aplikasi Abu Boiler dan Arang Kayu Sebagai Media Tumbuh Alternatif Bibit Kelapa Sawit (Elaeis guineensis Jacq.) di Pembibitan Awal. Jurnal Citra Widya Edukasi, 11(1), 11-20. 
Redho Anggara Nobriama, Erwin Pane \& Sumihar Hutapea, pengaruh pemberian pupuk organik cair kandang kelinci dan kompos limbah baglog pada pertumbuhan bibit Kakao (theobroma cacao l.)

Lakitan B. (2000). Dasar-dasar fisiologi tumbuhan: PT RajaGrafindo Persada.

Naibaho J, \& Nelvia N. Pemberian Kompos Kulit Buah Kakao pada Medium Ultisol untuk Pertumbuhan Bibit Kakao (Theobroma Cacao L). Riau University,

Oviyanti F, Syarifah S, \& Hidayah N. (2016). Pengaruh pemberian pupuk organik cair daun gamal (Gliricidia sepium (Jacq.) Kunth ex Walp.) terhadap pertumbuhan tanaman sawi (Brassica juncea L.). Jurnal Biota, 2(1), 61-67.

Saleh AR, \& Jayanti KD. (2017). Pengaruh Populasi Naungan terhadap Pertumbuhan Awal Tanaman Kakao (Theobroma cacao L.) di Lapangan. Agropet, 14(2).

Suwatanti E, \& Widiyaningrum P. (2017). Pemanfaatan MOL Limbah Sayur pada Proses Pembuatan Kompos. Jurnal Mipa, 40(1), 1-6.

Widiyaningrum P. (2016). Penggunaan EM4 dan MOL limbah tomat sebagai bioaktivator pada pembuatan kompos. Life Science, 5(1), 18-24.

Ulfa, S. (2019). EFEKTIVITAS BIOHERBISIDA DARI LIMBAH CAIR PULP KAKAO DALAM PENGENDALIAN BERBAGAI JENIS GULMA DI KEBUN MASYARAKAT KECAMATAN DELI TUA KABUPATEN DELI SERDANG. BIOLINK : Jurnal Biologi Lingkungan Industri Kesehatan, 5(2), 142-152.

Yunita, S., Hutapea, S., \& Rahman, A. (2017). Respon Pertumbuhan Tanaman Sawi Manis (Brassica juncea L.) Terhadap Pemberian Pupuk Organik Cair Dan Kompos Sekam Padi. Agrotekma: Jurnal Agroteknologi dan Ilmu Pertanian, 2(1), 65-80.

Syahputra, E., Astuti K, R., \& Indrawaty, A. (2017). Kajian Agronomis Tanaman Cabai Merah (Capsicum annum L.) Pada Berbagai Jenis Bahan Kompos. Agrotekma: Jurnal Agroteknologi dan Ilmu Pertanian, $1(2), 92-101$. 